\title{
Response of Bioinoculant Consortia on Nutrient Uptake, Forskolin Content (Diterpene) and Tuber Yield of Coleus (Coleus forskohlii (Willd) Briq.)
}

\author{
A.S. Noor Nawaz ${ }^{1}$, H.S. Imran Khan ${ }^{2}$ and K.R. Sreeramulu ${ }^{3}$ \\ ${ }^{1}$ Department of Agricultural Microbiology, UAS, Dharwad-580 005, Karnataka, India \\ ${ }^{2}$ Department of Plant Pathology, UA\&HS, Shimoga-577 204, Karnataka, India \\ ${ }^{3}$ Department of Microbiology, UAS, GKVK, Bangalore-560 065, Karnataka, India \\ *Corresponding author
}

\section{A B S T R A C T}

\begin{tabular}{|l|}
\hline Key w o r d s \\
Bioinoculants, \\
Forskolin, \\
Azotobacter, \\
Bacillus, \\
Trichoderma, \\
Mycorrhiza. \\
\hline Article Info \\
\hline Accepted: \\
24 February 2017 \\
Available Online: \\
10 March 2017 \\
\hline
\end{tabular}

A field experiment was conducted to assess the combined effect of bioinoculants on nutrient uptake, forskolin content (diterpene) and tuber yield of Coleus forskohlii (cutivar; K-8). The microbial inoculants such as Azotobacter chroococcum, Bacillus subtilis, Pseudomonas fluorescens, Glomus fasciculatum (VAM) were used. Bioagents such as Trichoderma harzianum and Pseudomonas fluorescens were used. Bioinoculants were examined along with graded levels of recommended dose of $\mathrm{N}$ and $\mathrm{P}_{2} \mathrm{O}_{5}$ with $100 \% \mathrm{~K}_{2} \mathrm{O}$ fertilizers. Nutrient uptake showed significant difference among the treatments. Forskolin estimation in tuberous roots quantitated by High Profile Liquid Chromatographic method and compared with standard procured from Natural Remedies, Bangalore. Forskolin in tuberous roots and tuber yield was maximum at harvest in the treatment of $100 \%$ NPK with combined inoculation of A. chroococcum, B. subtilis, T. harzianum, P. fluorescens and $G$. fasciculatum followed by plants inoculated with same consortia plus $75 \%$ NP plus $100 \% \mathrm{~K}$. The lowest nutrient uptake and forskolin content and tuber yield were recorded in uninoculated control plants supplemented with $50 \% \mathrm{NP}$ plus $100 \% \mathrm{~K}$. This clearly showed that economically advantageous yields can be obtained with $75 \%$ NP with $100 \%$ $\mathrm{K}$ and a saving of $25 \% \mathrm{~N}$ can be achieved by using the above microbial consortia. This could be attributed that due to the effective use of consortia of bioinoculants with graded level of inorganic fertilizers.

\section{Introduction}

Coleus (Coleus forskohlii (Willd.) Briq.) a member of lamiaceae is an Indian medicinal herb, rose by virtue of active diterpene $\left(\mathrm{C}_{22} \mathrm{H}_{34} \mathrm{O}_{7}\right.$; forskolin) present in the root extracts (Shah et al., 1980). Because of the continuous and destructive collection of tubers from its wild sources, made the species valuable and warranted its inclusion in the list of endangered species. The plant is grown in North Karnataka for its tuber, used as condiment in the preparation of pickles.
Forskolin has the unique property of activating almost all hormone sensitive adenylate cyclase enzymes in a biological system. Just 100 milligrams of pure forskolin costs about US \$85.00 (Gowda, 2000). In India, it is widely distributed in the dry hills of western Uttar Pradesh, Gujarat, parts of Orissa and Western Ghats of Karnataka. In ayurveda it has usage in treatment of heart diseases, abdominal colic, glaucoma, asthma, 
certain cancers, respiratory disorders, insomnia and convulsions (Ammon and Muller, 1985). Bioinoculants such as Azotobacter improves root system of the plant with increased uptake of $\mathrm{NO}_{3}, \mathrm{NH}_{4}, \mathrm{H}_{2} \mathrm{PO}_{4}, \mathrm{~K}$ and Fe. Many phosphate solubilising bacteria help to solubilize the inorganic phosphate such as rock phosphate, tricalcium phosphate, iron phosphate and aluminum phosphate by producing certain organic acids. The fixed phosphorus is mobilized the beneficial fungi like Arbuscular Mycorrhiza (AM fungi) into the plant system. They also mobilize the nutrients such as $\mathrm{Fe}, \mathrm{Cu}, \mathrm{Zn}$, Mo etc., to overcome the transplanting shock and water stress during drought conditions through root ramification process. The recent concept of eco-friendly technology and sustainability is most appropriate through use of bioinoculants in combination with inorganic fertilizers meet the crop nutrient needs reduces the rate of application of chemical $\mathrm{N}$ fertilizers by 18 $20 \%$ and increasing the yield to an extent of $20-25 \%$ but also supplement various plant growth promoting substances. The present investigation is focused to know the combined effect of bioinoculants with graded levels of inorganic fertilizers on plant nutrient uptake and forskolin content (a diterpenoid) and tuber yield.

\section{Materials and Methods}

Microbial Bioinoculants used in the experiment and their mass multiplication

The microbial inoculants viz., Azotobacter chroococcum ( $\mathrm{N}_{2}$ fixer) $\left(12 \times 10^{7} \mathrm{cfu}^{-1}\right)$, Bacillus subtilis $\left(9 \mathrm{x} 10^{8} \mathrm{cfu} \quad \mathrm{g}^{-1}\right)$ and Pseudomonas fluorescens $\left(6 \times 10^{8} \mathrm{cfu}^{-1}\right)$, Arbuscular Mycorrhizal fungus Glomus fasciculatum (12500 IP g $\mathrm{g}^{-1}$ ) were used in the study Trichoderma harzianum $\left(2 \times 10^{6} \mathrm{cfu} \mathrm{g}^{-1}\right)$ and $P$. fluorescens $\left(6 \times 10^{8} \mathrm{cfu} \mathrm{g}^{-1}\right)$ are used as bioagents. These bioinoculants were mass produced at Biofertilizers scheme, Department of Agricultural Microbiology,
UAS, Gandhi Krishi Vijnana Kendra, Bangalore.

\section{Site description, experimental design and} treatments

The field experiment was carried out at Sanjeevini Vatika, Division of Horticulture, University of Agricultural Sciences, GKVK, Bangalore which is situated at an elevation of $930 \mathrm{~m}$ above mean sea level with latitude of $12^{0} 58^{\prime}$ North and longitude of $77^{0} .35^{\prime}$ East. Microbiological investigations were done at Biofertilizer laboratory, Department of Agricultural Microbiology, UAS, GKVK, Bangalore. The experiment was laid out in Randomized Complete Block Design (RCBD) with 14 treatments replicated thrice having Gross plot size: $5.4 \mathrm{~m}^{2}(3.0 \mathrm{~m} \times 1.8 \mathrm{~m})$ net plot size of $1.35 \mathrm{~m}^{2}(1.5 \mathrm{~m} \times 0.9 \mathrm{~m})$, plant variety used: K8 (released by IIHR), recommended fertilizer dose: 40:60:50 kg NPK ha ${ }^{-1}$ and recommended dose of FYM: 10 ton $\mathrm{ha}^{-1}$. Forty days old healthy Coleus seedlings were transplanted on the ridges at a spacing of $45 \mathrm{cms}$ to main field. The treatment details as follows.

\begin{tabular}{|l|}
\hline \multicolumn{1}{|c|}{ Treatments } \\
\hline $\mathrm{T}_{1}-100 \% \mathrm{NPK}$ \\
\hline $\mathrm{T}_{2}-75 \% \mathrm{NP}+100 \% \mathrm{~K}$ \\
\hline $\mathrm{T}_{3}-50 \% \mathrm{NP}+100 \% \mathrm{~K}$ \\
\hline $\mathrm{T}_{4}-75 \% \mathrm{NP}+100 \% \mathrm{~K}+$ Azotobacter chroococcum + \\
Bacillus subtilis \\
\hline $\mathrm{T}_{5}-75 \% \mathrm{NP}+100 \% \mathrm{~K}+A . c+B . s+$ Trichoderma \\
harzianum \\
\hline $\mathrm{T}_{6}-75 \% \mathrm{NP}+100 \% \mathrm{~K}+A . c+B . s+$ Pseudomonas \\
fluorescens \\
\hline $\mathrm{T}_{7}-75 \% \mathrm{NP}+100 \% \mathrm{~K}+A . c+$ B. $s+$ Glomus \\
fasciculatum \\
\hline $\mathrm{T}_{8}-75 \% \mathrm{NP}+100 \% \mathrm{~K}+A . c+B . s+T . h+P . f+G . f$ \\
\hline $\mathrm{T}_{9}-50 \% \mathrm{NP}+100 \% \mathrm{~K}+A . c+B . s$ \\
\hline $\mathrm{T}_{10}-50 \% \mathrm{NP}+100 \% \mathrm{~K}+A . c+B . s+T . h$ \\
\hline $\mathrm{T}_{11}-50 \% \mathrm{NP}+100 \% \mathrm{~K}+A . c+B . s+P . f$ \\
\hline $\mathrm{T}_{12}-50 \% \mathrm{NP}+100 \% \mathrm{~K}+A . c+B . s+G . f$ \\
\hline $\mathrm{T}_{13}-50 \% \mathrm{NP}+100 \% \mathrm{~K}+A . c+B . s+T . h+P . f+G . f$ \\
\hline $\mathrm{T}_{14}-100 \% \mathrm{NPK}+A . c+B . s+T . h+P . f+G . f$ \\
\hline
\end{tabular}




\section{Microbial parameters}

The data pertaining to microbial population initial and at harvest viz., bacteria, fungi and actinomycetes in soil after harvest of the crop is presented in Table 1. The initial soil is sampling was done after land preparation and pooled by quadrant method. At harvest the treatment wise soil sampling was done and pooled. The microbial population was enumerated using serial dilution and plate count technique.

Populations of N-fixing and P-solubilizing microorganisms in crop rhizosphere soil after harvest

At harvest the treatment wise soil sampling was done and pooled using quadrant method. The microbial population of $\mathrm{N}$-fixing and $\mathrm{P}$ solubilizing microorganisms in crop rhizosphere soil after harvest was enumerated using serial dilution and plate count technique.

\section{Soil physico-chemical properties}

Soil $\mathrm{pH}$ was determined in $1: 2.5$, soil: water suspension by glass electrode using digital $\mathrm{pH}$ meter (Piper, 1957). The soil suspension was filtered and the electrical conductivity was measured using conductivity bridge and expressed in dS $\mathrm{m}^{-1}$ (Jackson, 1973). The organic carbon was estimated by Walkely and Black wet digestion method as described by Piper (1957).

The available nitrogen $\left(\mathrm{kg} \mathrm{ha}^{-1}\right)$ in the sample was determined by alkaline potassium permanganate method (Subbiah and Asija, 1956). The available phosphorus in the soil was extracted using Bray's extract. The extracted phosphorus was estimated by chlorostannous reduced molybdophosphoric acid blue colour method. The intensity of the blue colour was read by using spectronic-20 spectrophotometer (Jackson, 1973). The available potassium content in the soil was determined by Flame photometer method as described by Muhr et al., (1965).

\section{Fertilizer}

The amount of inoculum applied to each plant was standardized by following package of practices recommended by UAS, GKVK, Bangalore. The lignite based A. chroococcum inoculum was applied at $5 \mathrm{~g}$ per plant after assessing the population per gram carrier. $T$. harzianum had a population of $2 \times 10^{6} \mathrm{cfu}^{-1}$ was applied at $2 \mathrm{~g}$ per plant and $P$. fluorescens and $B$. subtilis which has attained a population of $10^{8}$ cells per ml mixed with lignite powder and applied to crop plants at $5 \mathrm{~g}$ per plant.

The air-dried AM fungal inoculum contained infected root bits of AM fungi and Chlamydospores served as inoculums and applied to each plant was $10 \mathrm{~g}$ which had a population of 12500 IP (infective propagules). The recommended dose of fertilizer (IIHR recommendation) was applied in the form of urea, single super phosphate and muriate of potash respectively as per the treatments. The crop was harvested after five months of transplanting.

\section{Dry matter accumulation and plant analysis}

Since the economic part of the crop was tuberous roots, the plants were dug. After recording the observations at harvest they were dried were subjected to chemical analysis. Tubers were chopped and shade dried to a constant weight and tuber dry weight per plant was recorded in grams and later converted to $\mathrm{kg}$ per hectare.

Finely grounded plant sample powder was used for estimating the nutrient uptake by the plant for total nitrogen, phosphorus and potassium. 


\section{Plant analysis}

The nitrogen uptake in the plant parts was determined by Kjeldhal method as outlined by Piper (1957). The phosphorus uptake in the plant was determined by Vanadomolybdate phosphoric yellow colour method (Jackson, 1973).

\section{Extraction and estimation of Forskolin content in Coleus}

\section{Preparation of standards}

Fifty $\mu \mathrm{g} / \mathrm{ml} \mathrm{P}$ standard was prepared from analar grade potassium dihydrogen phosphate. The chemical (0-2192g) was taken in $1000 \mathrm{ml}$ volumetric flask and dissolved in distilled water. Twenty five $\mathrm{ml}$ of $7 \mathrm{~N} \cdot \mathrm{H}_{2} \mathrm{SO}_{4}$ was added and volume made up to $1000 \mathrm{ml}$ to give $50 \mu \mathrm{g} / \mathrm{ml} \mathrm{P}$. Different quantities of this standard solution were taken in $50 \mathrm{ml}$ volumetric flasks to give $5,10,20,30,40$, and $50 \mu \mathrm{g} / \mathrm{ml}$. $10 \mathrm{ml}$ vanadomolybdate reagent was added and the volume made up to $50 \mathrm{ml}$. A blank was prepared without the standard solution.

The color was read colorimetrically at $420 \mathrm{~nm}$ in spectronic 20 and the standard curve was drawn.

\section{Estimation of Forskolin content}

High Performance Liquid Chromatography Technique (HPLC) was used to separate Forskolin from the extract of Coleus forskohlii equipped with following specifications.

\section{Chromatographic system}

Waters HPLC system; Pumps: Water 515; Binary gradient operated under isocratic conditions. Detector: Water 2487 dual absorbance detector. Software: Millennium 32 chromatograph software.

\section{Chromatographic conditions}

Mobile phase: HPLC acetonitrile grade: Millipore water (55:45). Flow rate: $1.8 \mathrm{ml}$ /min. Detection wavelength: $220 \mathrm{~nm}$. Injection volume: Symmetry C18 column (4.6mm x $250 \mathrm{~mm})$

\section{Procedure}

Reference standard forskolin in pure form was obtained from Natural Remedies, Bangalore. About $25 \mathrm{mg}$ was weighed accurately and transferred into a $25 \mathrm{ml}$ volumetric flask. Then it was dissolved in 15 $\mathrm{ml}$ of acetonitrile and volume was made up to $25 \mathrm{ml}$ with acetonitrile and mixed well and then used as a reference standard.

\section{Sample preparation}

Representative samples from each of the treatments $(3 \mathrm{~g})$ was weighed and transferred to a $250 \mathrm{ml}$ beaker. The extract was obtained with $50 \mathrm{ml}$ of acetonitrile by warming on a water bath for about 20 minutes and then the extract was transferred to a $250 \mathrm{ml}$ beaker.

The process was repeated 4-5 times till the raw material was completely extracted or till the extract becomes colorless. All extracts collected in $250 \mathrm{ml}$ beaker and concentrated it to below $100 \mathrm{ml}$, cooled to room temperature then transferred to a $100 \mathrm{ml}$ volumetric flask and volume was made up to $100 \mathrm{ml}$ with acetonitrile, mixed well and filtered through $0.45 \mu$ membrane.

\section{Extraction}

Standard forskolin $(25 \mathrm{mg})$ was weighed and transferred to $100 \mathrm{ml}$ volumetric flask. Then it was dissolved in $50 \mathrm{ml}$ of acetonitrile by gently heating on water bath, cooled to room temperature and volume was made to $100 \mathrm{ml}$ 
with acetonitrile, mixed well and filtered through $0.45 \mu$ membrane.

\section{Spent}

A known quantity (10 g) of sample was weighed accurately and the procedure was repeated as in the case of raw material extraction. The standard preparation was subjected to chromatography by injecting $20 \mu 1$ to the HPLC system.
The RSD [(Relative Standard Deviation) not more than 2 per cent was calculated for at least 3 replicated injections and tailing factor NMT 1.5. The sample preparation was chromatographed for at least twice and the forskolin per cent was calculated from the peak responses by using the following formula.

\section{Calculations}

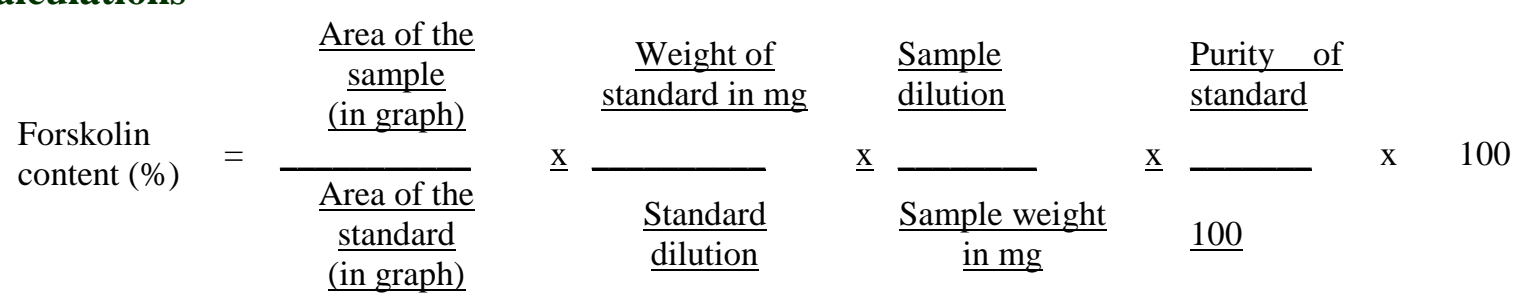

\section{Statistical analysis}

The data collected in this study was subjected to statistical analysis suitable to RCBD. Duncan's multiple range test (DMRT) was done to separate the treatment means (Little and Hills, 1978).

\section{Results and Discussion}

\section{Microbial parameters}

\section{General microflora at harvest}

The maximum bacterial population was found in the rhizosphere soil of the treatment $\left(\mathrm{T}_{14}\right)$ which had A. chroococcum, B. subtilis, $T$. harzianum, $P$. fluorescens and $G$. fasciculatum with $100 \%$ NPK $\left(41.0 \times 10^{6} \mathrm{cfu}\right.$ $\mathrm{g}^{-1}$ soil) which was statistically on par with the treatment $\left(\mathrm{T}_{8}\right)$ inoculated with same microbial consortia with $75 \% \mathrm{~N}$ and $\mathrm{P}$ plus full dose of $\mathrm{K}\left(40.0 \times 10^{6} \mathrm{cfu} \mathrm{g}^{-1}\right.$ of soil). The lowest bacterial population was found in the rhizosphere soils of uninoculated plot $\left(\mathrm{T}_{3}\right)$ treated only with $50 \% \mathrm{~N}$ and $\mathrm{P}$ plus full dose

$\mathrm{K}\left(15.0 \times 10^{6} \mathrm{cfu}^{-1}\right.$ of soil). The similar trend was found with respect to fungal and actinomycetes population in treatment $\left(\mathrm{T}_{14}\right)$

$\left(31.90 \times 10^{3} \mathrm{cfu} \mathrm{g}^{-1}\right.$ soil) and $\left(26.90 \times 10^{4} \mathrm{cfu}\right.$ $\mathrm{g}^{-1}$ soil) which was statistically on par with the treatment $\left(\mathrm{T}_{8}\right)\left(30.0 \times 10^{3} \mathrm{cfu} \mathrm{g}^{-1}\right.$ of soil $)$ and (27.0 X $10^{4} \mathrm{cfu} \mathrm{g}^{-1}$ of soil) respectively, the lowest fungal and actinomycetes population was found in the rhizosphere soils of uninoculated plot $\left(\mathrm{T}_{3}\right)$ treated only with 50 $\% \mathrm{~N}$ and $\mathrm{P}$ plus full dose $\mathrm{K}\left(13.0 \times 10^{3} \mathrm{cfu} \mathrm{g}^{-}\right.$ ${ }^{1}$ of soil) and $\left(10.76 \times 10^{4} \mathrm{cfu}^{-1}\right.$ of soil) respectively (Table 1 ). Treatments differed significantly with respect to bacterial, fungal and actinomycetes population.

\section{Populations of N-fixing and P-solubilizing microorganisms in crop rhizosphere soil after harvest}

The maximum Azotobacter population was found in the rhizosphere soil of the treatment ( T $_{14}$ ) which had A. c, B. s, T. h, P.f and G. $f$ with $100 \%$ NPK (17.41 X $10^{6} \mathrm{cfu} \mathrm{g}^{-1}$ soil) which was statistically on par with the treatment $\left(\mathrm{T}_{8}\right)$ inoculated with same microbial 
consortia with $75 \% \mathrm{~N}$ and $\mathrm{P}$ plus full dose of $\mathrm{K}\left(17.00 \times 10^{6} \mathrm{cfu} \mathrm{g}^{-1}\right.$ of soil). The lowest Azotobacter population was found in the rhizosphere soils of uninoculated plot $\left(\mathrm{T}_{3}\right)$ treated only with $50 \% \mathrm{~N}$ and $\mathrm{P}$ plus full dose $\mathrm{K}\left(7.07 \times 10^{6} \mathrm{cfu} \mathrm{g}^{-1}\right.$ soil).

Similar trend was observed pertaining to maximum phosphate solubilizing bacterial population was recorded in the rhizosphere soils of treatment $\mathrm{T}_{14}\left(12.13 \times 10^{6} \mathrm{cfu} \mathrm{g}^{-1}\right.$ soil $)$ followed by soils treated with $\mathrm{T}_{8}\left(11.49 \times 10^{6}\right.$ cfu $\mathrm{g}^{-1}$ soil). These two treatments did not differ significantly with each other. The lowest phosphate solubilizing bacterial population was recorded in uninoculated $\left(\mathrm{T}_{3}\right)$ soils which received $50 \% \mathrm{~N}$ and $\mathrm{P}$ with $100 \%$ $\mathrm{K}\left(5.90 \times 10^{6} \mathrm{cfu} \mathrm{g}^{-1}\right.$ soil $)$.
Maximal Trichoderma population was recorded in the treatment $\mathrm{T}_{14}\left(15.67 \times 10^{3} \mathrm{cfu}\right.$ /g soil). The treatment $\left(\mathrm{T}_{3}\right)$ having $50 \% \mathrm{~N}$ and $\mathrm{P}$ with full dose of $\mathrm{K}$ but without microbial inoculation showed lowest Trichoderma population $\left(4.00 \times 10^{3} \mathrm{cfu} \mathrm{g}^{1}\right.$ soil).

Similarly, the maximum population of $P$. fluorescens was found in the treatment $\mathrm{T}_{14}$ $\left(16.18 \times 10^{6} \mathrm{cfu} \mathrm{g}^{-1}\right.$ soil) whereas that of minimum was observed in uninoculated $\left(\mathrm{T}_{3}\right)$ treatment which had only $50 \% \mathrm{~N}$ and $\mathrm{P}$ with full dose of $\mathrm{K}\left(4.25 \times 10^{6} \mathrm{cfu} \mathrm{g}^{-1}\right.$ soil) (Table 2). Treatments differed significantly with respect to $\mathrm{N}$-fixing and $\mathrm{P}$ solubilizing microorganisms.

Table.1 Initial soil microbial population and at harvest of Coleus rhizosphere

\begin{tabular}{|c|c|c|c|c|c|c|}
\hline \multirow[b]{3}{*}{ Treatments } & \multicolumn{6}{|c|}{ General microbial population $\left(\mathrm{Cfu}^{-1}\right.$ soil $)$} \\
\hline & \multicolumn{3}{|c|}{ Initial } & \multicolumn{3}{|c|}{ At harvest } \\
\hline & $\begin{array}{c}\text { Bacteria } \\
(\text { No.x } \\
\left.10^{6}\right)\end{array}$ & $\begin{array}{c}\text { Fungi } \\
\left(\mathrm{No.}^{\mathrm{x}}\right. \\
\left.\mathbf{1 0}^{\mathbf{3}}\right)\end{array}$ & $\begin{array}{l}\text { Actinomycetes } \\
\left(\text { No. } \times 1^{4}\right)\end{array}$ & $\begin{array}{c}\text { Bacteria } \\
(\text { No.x } \\
\left.\mathbf{1 0}^{6}\right)\end{array}$ & $\begin{array}{c}\text { Fungi } \\
(\mathrm{No.} x \\
\left.10^{3}\right)\end{array}$ & $\begin{array}{l}\text { Actinomycetes } \\
\left(\text { No. } \times 10^{4}\right)\end{array}$ \\
\hline $\mathbf{T}_{1}$ & \multirow{14}{*}{18.00} & \multirow{14}{*}{14.75} & \multirow{14}{*}{10.00} & 18.20 & 15.50 & 12.05 \\
\hline $\mathbf{T}_{2}$ & & & & 16.00 & 15.53 & 13.25 \\
\hline $\mathbf{T}_{\mathbf{3}}$ & & & & 15.00 & 13.00 & 10.76 \\
\hline $\mathbf{T}_{4}$ & & & & 36.70 & 20.33 & 20.00 \\
\hline $\mathbf{T}_{5}$ & & & & 25.90 & 28.10 & 24.70 \\
\hline $\mathbf{T}_{6}$ & & & & 36.70 & 21.03 & 17.73 \\
\hline $\mathbf{T}_{7}$ & & & & 33.25 & 20.50 & 20.23 \\
\hline $\mathbf{T}_{8}$ & & & & 40.00 & 30.00 & 27.00 \\
\hline $\mathbf{T}_{9}$ & & & & 29.70 & 25.80 & 26.93 \\
\hline$T_{10}$ & & & & 29.50 & 27.90 & 22.50 \\
\hline $\mathbf{T}_{11}$ & & & & 36.50 & 23.10 & 20.23 \\
\hline$T_{12}$ & & & & 25.70 & 22.95 & 18.00 \\
\hline$T_{13}$ & & & & 37.20 & 28.25 & 17.00 \\
\hline $\mathbf{T}_{14}$ & & & & 41.00 & 31.90 & 26.90 \\
\hline SEm \pm & & & & 0.239 & 0.323 & 0.146 \\
\hline $\mathrm{CD}(0.05)$ & & & & 0.695 & 0.940 & 0.425 \\
\hline
\end{tabular}

Notations:

A. $c=$ Azotobacter chroococcum $P . f=$ Pseudomonas fluorescens NS =Non significant
B. $s=$ Bacillus subtilis

G. $f=$ Glomus fasciculatum

* =Significant at 0.05

\section{T. $h=$ Trichoderma harzianum}


Table.2 Population of introduced N- fixing and P-solubilizing microorganisms in rhizosphere soil of Coleus at harvest

\begin{tabular}{|c|c|c|c|c|}
\hline \multirow[t]{2}{*}{ Treatments } & \multicolumn{4}{|c|}{ Microbial population ( $\mathrm{Cfu}^{-1}$ of soil) } \\
\hline & $\begin{array}{c}\text { Azotobacter } \\
\left(\text { No. } \times 10^{6}\right)\end{array}$ & $\begin{array}{c}\text { Bacillus } \\
\left(\text { No. } \times 10^{6}\right)\end{array}$ & $\begin{array}{c}\text { Trichoderma } \\
\left(\text { No. } \times 10^{3}\right)\end{array}$ & $\begin{array}{l}\text { Pseudomonas } \\
\left(\text { No. } \times 1^{6}\right)\end{array}$ \\
\hline $\mathbf{T}_{1}$ & 8.21 & 6.54 & 4.35 & 7.19 \\
\hline $\mathbf{T}_{2}$ & 8.02 & 6.00 & 4.31 & 5.36 \\
\hline $\mathbf{T}_{3}$ & 7.07 & 5.90 & 4.00 & 4.25 \\
\hline $\mathbf{T}_{4}$ & 15.53 & 9.78 & 4.04 & 7.38 \\
\hline $\mathbf{T}_{5}$ & 16.27 & 10.37 & 13.16 & 8.01 \\
\hline $\mathbf{T}_{6}$ & 15.94 & 9.41 & 5.71 & 14.89 \\
\hline $\mathbf{T}_{7}$ & 16.54 & 11.00 & 5.64 & 8.87 \\
\hline $\mathbf{T}_{8}$ & 17.00 & 11.49 & 14.86 & 15.09 \\
\hline $\mathbf{T}_{9}$ & 8.43 & 7.00 & 7.04 & 9.00 \\
\hline $\mathbf{T}_{10}$ & 12.17 & 7.49 & 12.68 & 9.49 \\
\hline$T_{11}$ & 9.47 & 6.34 & 7.13 & 14.63 \\
\hline$T_{12}$ & 12.39 & 8.85 & 9.01 & 12.11 \\
\hline$T_{13}$ & 13.99 & 9.75 & 12.00 & 13.03 \\
\hline $\mathbf{T}_{14}$ & 17.41 & 12.13 & 15.67 & 16.18 \\
\hline $\mathrm{SEm} \pm$ & 0.75 & 0.61 & 0.66 & 0.87 \\
\hline $\mathrm{CD}(0.05)$ & 2.18 & 1.77 & 1.93 & 2.53 \\
\hline
\end{tabular}

Table.3 Effect of biofertilizers on dry matter accumulation in Coleus

\begin{tabular}{|c|c|c|c|}
\hline \multirow{2}{*}{ Treatments } & \multicolumn{2}{|c|}{ Dry matter $\left(\mathbf{g ~ p l a n t}^{\mathbf{- 1}}\right)$} & \multirow{2}{*}{$\begin{array}{c}\text { Total Biomass } \\
\text { (g plant }^{\mathbf{1}} \text { ) }\end{array}$} \\
\cline { 2 - 3 } & Aerial shoot & Roots & 225.15 \\
\hline $\mathbf{T}_{\mathbf{1}}$ & 168.28 & 56.87 & 161.41 \\
\hline $\mathbf{T}_{\mathbf{2}}$ & 121.78 & 39.59 & 140.65 \\
\hline $\mathbf{T}_{\mathbf{3}}$ & 105.38 & 35.27 & 246.21 \\
\hline $\mathbf{T}_{\mathbf{4}}$ & 183.58 & 62.63 & 261.40 \\
\hline $\mathbf{T}_{\mathbf{5}}$ & 195.89 & 65.51 & 252.49 \\
\hline $\mathbf{T}_{\mathbf{6}}$ & 188.9 & 63.59 & 271.10 \\
\hline $\mathbf{T}_{\mathbf{7}}$ & 204.15 & 66.95 & 279.05 \\
\hline $\mathbf{T}_{\mathbf{8}}$ & 211.67 & 68.15 & 193.71 \\
\hline $\mathbf{T}_{\mathbf{9}}$ & 145.48 & 48.23 & 205.40 \\
\hline $\mathbf{T}_{\mathbf{1 0}}$ & 154.53 & 50.87 & 196.05 \\
\hline $\mathbf{T}_{\mathbf{1 1}}$ & 147.84 & 48.23 & 214.73 \\
\hline $\mathbf{T}_{\mathbf{1 2}}$ & 160.98 & 53.75 & 232.70 \\
\hline $\mathbf{T}_{\mathbf{1 3}}$ & 171.99 & 60.71 & 288.10 \\
\hline $\mathbf{T}_{\mathbf{1 4}}$ & 217.07 & 71.03 & 5.96 \\
\hline SEm \pm & 2.42 & 3.56 & 17.28 \\
\hline CD $(\mathbf{0 . 0 5})$ & 7.0 & 10.28 & \\
\hline
\end{tabular}


Table.4 Effect of biofertilizers on plant nutrient uptake and available NPK status of soil after harvest of Coleus

\begin{tabular}{|c|c|c|c|c|c|c|}
\hline \multirow{2}{*}{ Treatments } & \multicolumn{3}{|c|}{ Plant nutrient uptake (\%) } & \multicolumn{3}{|c|}{ Available nutrients $\left(\mathrm{kg} \mathrm{ha}^{-1}\right)$} \\
\hline & $\mathbf{N}$ & $\mathbf{P}_{2} \mathbf{O}_{5}$ & $\mathbf{K}_{2} \mathbf{O}$ & $\mathbf{N}$ & $\mathbf{P}$ & $\mathbf{K}$ \\
\hline $\mathbf{T}_{1}$ & 1.18 & 0.35 & 0.96 & 334.88 & 31.54 & 275.25 \\
\hline $\mathbf{T}_{2}$ & 1.09 & 0.27 & 0.90 & 295.70 & 21.34 & 246.23 \\
\hline $\mathbf{T}_{3}$ & 1.05 & 0.25 & 0.05 & 288.19 & 20.37 & 244.00 \\
\hline $\mathbf{T}_{4}$ & 1.19 & 0.36 & 0.98 & 346.87 & 32.67 & 284.75 \\
\hline $\mathbf{T}_{5}$ & 1.23 & 0.37 & 1.05 & 363.91 & 37.45 & 307.00 \\
\hline $\mathbf{T}_{6}$ & 1.21 & 0.36 & 0.98 & 348.63 & 35.61 & 288.25 \\
\hline $\mathbf{T}_{7}$ & 1.24 & 0.38 & 1.06 & 366.99 & 38.66 & 310.00 \\
\hline $\mathbf{T}_{8}$ & 1.25 & 0.39 & 1.08 & 378.69 & 39.84 & 314.00 \\
\hline $\mathbf{T}_{9}$ & 1.10 & 0.28 & 0.92 & 307.52 & 22.79 & 257.50 \\
\hline$T_{10}$ & 1.13 & 0.32 & 0.95 & 325.64 & 24.45 & 270.10 \\
\hline$T_{11}$ & 1.12 & 0.30 & 0.94 & 312.53 & 23.27 & 258.75 \\
\hline$T_{12}$ & 1.17 & 0.33 & 0.96 & 327.48 & 27.24 & 271.50 \\
\hline$T_{13}$ & 1.19 & 0.35 & 098 & 339.40 & 31.79 & 282.75 \\
\hline$T_{14}$ & 1.27 & 0.41 & 1.11 & 383.27 & 42.80 & 318.37 \\
\hline SEm \pm & 0.02 & 0.01 & 0.02 & 2.98 & 2.09 & 3.27 \\
\hline $\mathrm{CD}(0.05)$ & 0.06 & 0.03 & 0.05 & 8.61 & 6.03 & 9.44 \\
\hline
\end{tabular}

Table.5 Forskolin content, Forskolin yield and tuber yield in Coleus as influenced by biofertilizers

\begin{tabular}{|c|c|c|c|}
\hline Treatments & $\begin{array}{c}\text { Forskolin content } \\
(\% \mathrm{w} / \mathrm{w})\end{array}$ & $\begin{array}{l}\text { Forskolin yield } \\
\left(\mathrm{Kg} \mathrm{ha}^{-1}\right)\end{array}$ & $\begin{array}{c}\text { Tuber yield } \\
\left(\mathrm{t} \mathrm{ha}^{-1}\right)\end{array}$ \\
\hline$T_{1}$ & 0.62 & 13.03 & 11.69 \\
\hline $\mathbf{T}_{2}$ & 0.56 & 8.18 & 8.69 \\
\hline $\mathbf{T}_{3}$ & 0.49 & 6.29 & 8.05 \\
\hline $\mathbf{T}_{4}$ & 0.66 & 15.18 & 12.01 \\
\hline $\mathbf{T}_{5}$ & 0.69 & 16.66 & 12.71 \\
\hline$T_{6}$ & 0.67 & 15.55 & 12.17 \\
\hline $\mathbf{T}_{7}$ & 0.70 & 17.03 & 12.76 \\
\hline $\mathbf{T}_{8}$ & 0.75 & 18.93 & 12.87 \\
\hline$T_{9}$ & 0.56 & 9.99 & 10.02 \\
\hline$T_{10}$ & 0.60 & 11.85 & 10.77 \\
\hline$T_{11}$ & 0.58 & 10.79 & 10.11 \\
\hline$T_{12}$ & 0.61 & 12.22 & 10.07 \\
\hline$T_{13}$ & 0.65 & 14.44 & 10.97 \\
\hline$T_{14}$ & 0.78 & 20.37 & 13.49 \\
\hline SEm \pm & 0.023 & 0.41 & 0.53 \\
\hline $\mathrm{CD}(0.05)$ & 0.068 & 0.12 & 1.60 \\
\hline
\end{tabular}


Fig.1 Chromatogram showing Forskolin standard (A) and Coleus plant sample (B) in Coleus tubers

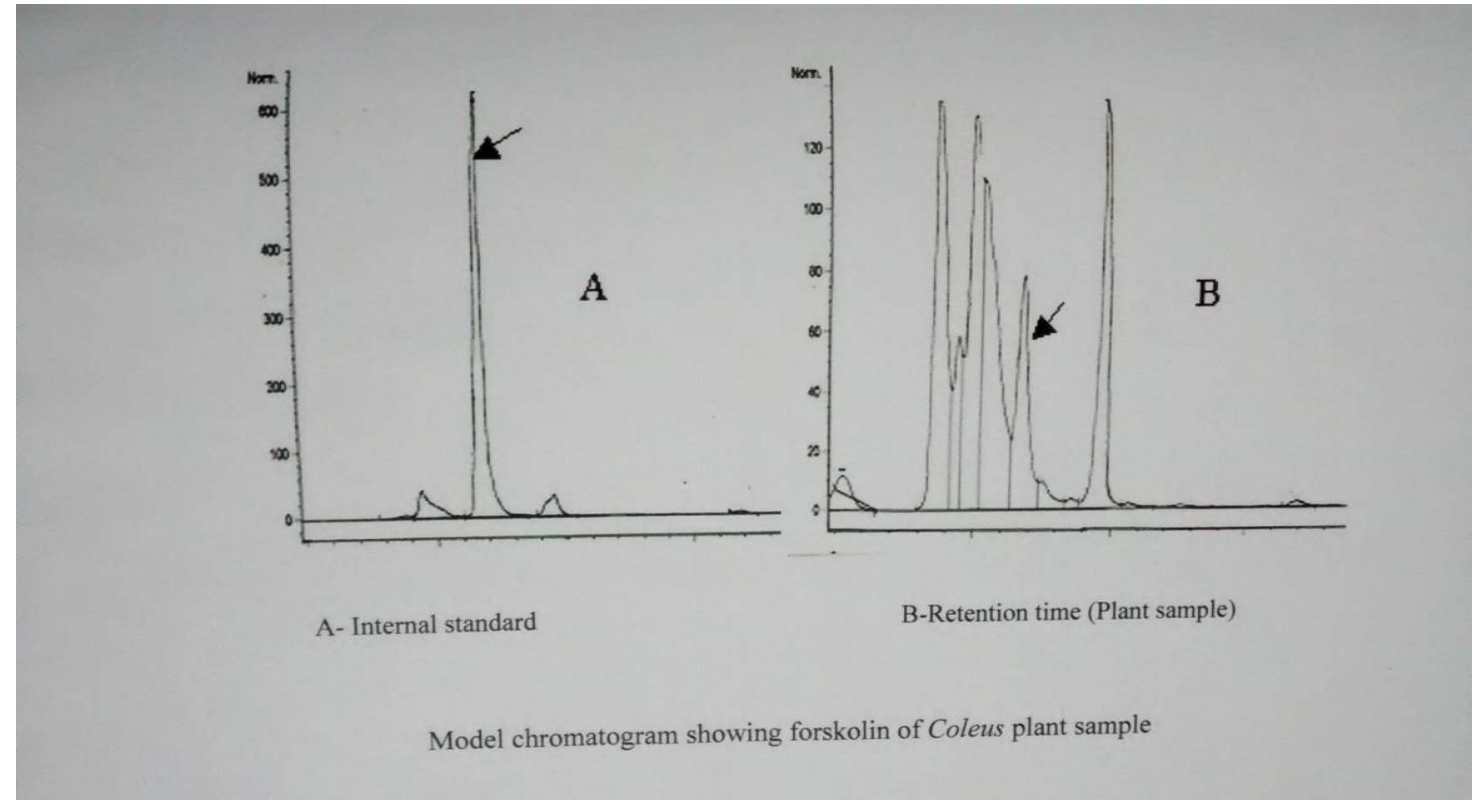

\section{Biomass accumulation $\left(\mathrm{g} \mathrm{plant}^{-1}\right)$ at harvest}

The maximum total biomass was accumulated in the plants treated with $\left(\mathrm{T}_{14}\right) 100$ per cent NPK with A. c, B. s, T. h, P. f. and G. $f(288.1$ g plant $\left.{ }^{-1}\right)$ followed by treatment $\left(\mathrm{T}_{8}\right) 75 \% \mathrm{~N}$ and $\mathrm{P}+100 \% \mathrm{~K}+$ same microbial consortia (279.05 g plant $^{-1}$ ) followed by $\left(\mathrm{T}_{7}\right) 75 \% \mathrm{~N}$ and $\mathrm{P}+100 \% \mathrm{~K}$ with $A . c, B . s$ and $G . f$ $\left(271.1 \mathrm{~g} \mathrm{plant}^{-1}\right)$. The lowest biomass was recorded in uninoculated treatment plants supplemented only with $50 \% \mathrm{~N}$ and $\mathrm{P}$ with full dose of $\mathrm{K}$ (140.65g plant ${ }^{-1}$ ) (Table 3). The greater uptake of nutrients can be related to higher dry matter production due to greater accumulation of metabolites in Coleus (Ravikumar et al., 2012). Nagappa and Thirumala (2014) showed that growth and biomass accumulation in Coleus vettiveroides were found to be significant with the application of FYM along with biofertilizer as compared with sole application of FYM or inorganic fertilizer.

Nutrient uptake (\%): Plants received nutrients as per $\left(\mathrm{T}_{14}\right)$ where the maximum tissue nitrogen, phosphorus and potassium content was recorded supplemented with $A$. $c$, B. s, T. h, P. f and G. $f$ with $100 \%$ NPK (1.27, 0.41 and $1.11 \%$ ) followed by treatment $\left(\mathrm{T}_{8}\right)$ inoculated with same microbial consortia along with $75 \%$ NP plus $100 \% \mathrm{~K}(1.25,0.39$ and $1.08 \%$ ) and the lowest tissue nitrogen was observed in the control treatment $\left(\mathrm{T}_{3}\right)$ which received only $50 \%$ NP plus $100 \% \mathrm{~K}$ $(1.05,0.25$ and $0.05 \%)$ (Table 4).

\section{Available N, $P$ and $K$ status of soil after harvest of the crop $\left(\mathrm{kg} \mathrm{ha}^{-1}\right)$}

The maximum amount of available $\mathrm{N}, \mathrm{P}$ and $\mathrm{K}$ in soil was recorded in the treatment combination $\left(\mathrm{T}_{14}\right) \quad 100$ per cent NPK inoculated with $A . c, B . s, T . h, P . f$ and $G . f$ with full recommended NPK (383.27, 42.80 and $318.37 \mathrm{~kg} \mathrm{ha}^{-1}$ ) followed by treatment $\left(\mathrm{T}_{8}\right) 75 \% \mathrm{~N}$ and $\mathrm{P}$ plus full dose of $\mathrm{K}$ inoculated with same microbial consortia (378.69, 39.84 and $\left.314.0 \mathrm{~kg} \mathrm{ha}^{-1}\right)$. The lowest $\mathrm{N}$ availability was recorded in uninoculated control treatment $\left(\mathrm{T}_{3}\right)$ having $50 \% \mathrm{~N}$ and $\mathrm{P}$ plus full dose of $\mathrm{K}$ (288.19, 20.37 and 244.0 
$\mathrm{kg} \mathrm{ha}{ }^{-1}$ ) (Table 4). The available nitrogen, phosphorus and potassium in the soil after harvest of the crop differed significantly among the treatments. Ravikumar et al., (2012) reported that highest NPK status and uptake in plants could be attributed to the combined application of biofertilizers which helped better availability and absorption of nutrients by the plants.

\section{Tuber yield, Forskolin content of tubers}

The maximum tuber yield ( $\left.\mathrm{t} \mathrm{ha}^{-1}\right)$ and forskolin content (\%) were recorded in the treatment combination $\left(\mathrm{T}_{14}\right)$ inoculated with A. c, B. s, T. h, P. $f$ and $G . f$ with $100 \%$ NPK $(13.49,0.78 \%)$ followed by treatment $\left(\mathrm{T}_{8}\right)$ inoculated with same microbial consortia along with $75 \% \mathrm{NP}$ plus full dose of $\mathrm{K}$ $(12.87,0.75 \%)$ which was statistically on par with the treatment $\left(\mathrm{T}_{7}\right)$ having the combined inoculation of $A . c, B . s$ and $G . f$ (12.76, $0.70 \%)$. The control treatment supplemented with $50 \%$ NP plus full dose $\mathrm{K}$ showed the lowest tuber yield and forskolin content (8.05, $0.49 \%$ ) (Table 5). The higher yield attributed to the combined effect of bioinoculants and with inorganic fertilizers (Mazumdar et al., 2002). High performance liquid chromatographic profile has shown accurate determination and quantification of forskolin wherein the RT is 6.8 minutes (Fig 1).

\section{Forskolin yield}

The maximum forskolin yield was recorded in the tubers of plants treated with $\left(\mathrm{T}_{14}\right) A . c, B$. s, T. $h, P . f$ and $G$. $f$ with $100 \%$ NPK $(20.37$ $\left.\mathrm{kg} \mathrm{ha}^{-1}\right)$ followed by treatment $\left(\mathrm{T}_{8}\right)$ inoculated with same microbial consortia with $75 \% \mathrm{~N}$ and $\mathrm{P}$ plus full dose of $\mathrm{K}\left(18.93 \mathrm{~kg} \mathrm{ha}^{-1}\right)$ which was statistically on par with treatment $\left(\mathrm{T}_{7}\right)$ having combined inoculation of $A . c, B . s$ and $G$. $f$ with $75 \% \mathrm{~N}$ and $\mathrm{P}$ plus full dose of $\mathrm{K}\left(17.03 \mathrm{~kg} \mathrm{ha}^{-1}\right)$. The control treatment $\left(\mathrm{T}_{3}\right)$ supplemented with $50 \% \mathrm{~N}$ and $\mathrm{P}$ plus full dose $\mathrm{K}$ showed the lowest forskolin yield (6.29 $\mathrm{kg} \mathrm{ha}^{-1}$ ) (Table 5).

In conclusion the results clearly reveal that bioinoculants with graded different levels of nitrogen and phosphorus application showed beneficial effect on Coleus nutrient uptake, forskolin content and tuber yield. Therefore maximum NPK content in plant tissue was noticed in plants supplemented with $100 \%$ NPK plus consortia of bioinoculants whereas the lowest available NPK was recorded in uninoculated control plants which had only 50 $\%$ NP with full dose of K. Similarly, for NPK availability in soil after harvest of the crop was found maximum in the treatment of 100 $\%$ NPK plus consortia compared to uninoculated control soil that showed lowest available NPK. The forskolin content and tuber yield was also found highest in the treatment of $100 \%$ NPK with consortia and that of lowest in the tubers of uninoculated control plants. Maximum tuber yield can be obtained in plants treated with $100 \%$ NPK along with combined inoculation of A.c, B.s, T.h, P.f and G.f. The next best superior yield was in the treatment of $75 \% \mathrm{NP}$ plus full dose of $\mathrm{K}$ with microbial consortia which were found statistically significant over $50 \%$ NP plus $100 \% \mathrm{~K}$ alone. This clearly shows that economically advantageous yields can be obtained with $75 \% \mathrm{~N}$ and $\mathrm{P}$ with full dose of $\mathrm{K}$ and a saving of $25 \% \mathrm{~N}$ can be achieved by using the above microbial consortia.

\section{References}

Ammon, H.P.T. and Muller, A.B. 1985. Forskolin: From an Ayurvedic remedy to a modern agent. Planta Medica, 46: 473-477.

Gowda, S. 2000. Coleus forskohlii, Agro India, August, 2000.p.27

Jackson, M.L. 1973. Soil chemical analysis, Pub: Asia publishing house, New Delhi, pp. 468-469. 
Little, T.M. and Hills, F.J. 1978. Agricultural experimentation. John Wiley and Sons Inc. USA.

Mazumdar, B., Venkatesh, M.S. and Kumar, K. 2002. Effect of nitrogen and FYM on yield and nutrient uptake of turmeric and different forms of inorganic build up in an acidic Alfisol of Meghalaya. Indian J. Agri. Sci., 72(9): 528-531.

Muhr, G.R., Data, M.P. and Dohanve, R.L. 1965. Soil testing in India, U.S.A.I.D., New Delhi, pp.44-46.

Nagappa, D. and Thirumala, S. 2014. Effect of biofertilizers on growth and biomass of Coleus vettiveroides. Int. J. Adv. Agric. Sci. and Technol., 3(1): 53-57.
Piper, C.S. 1957. Soil and Plant Analysis, Hans Publishers, New York.

Ravikumar, M., Venkatesha, J., Niranjana, K.S. and Gurumurthy, B. R. 2012. Effect of integrated nutrient management on tuber yield and quality and nutrient uptake in Coleus forskohlii Briq., J. Root Crops, 38(2): 142-146.

Shah, V., Bhat, S.V., Bajwa, B.S., Domaenr, H., and De Souza, N.T. 1980. The occurrence of forskolin in Lamiaceae, Planta Medica, 39(2): 183-185.

Subbaiah, B.B. and Asija, G.L. 1956. A rapid procedure for estimation of available nitrogen in soils. Curr. Sci., 25(8): 259260.

\section{How to cite this article:}

Noor Nawaz, A.S., H.S. Imran Khan and Sreeramulu, K.R. 2017. Response of Bioinoculant Consortia on Nutrient Uptake, Forskolin Content (Diterpene) and Tuber Yield of Coleus (Coleus forskohlii (Willd) Briq.). Int.J.Curr.Microbiol.App.Sci. 6(3): 2315-2325. doi: http://doi.org/10.20546/ijcmas.2017.603.265 